Article

\title{
Environmentally Friendly Approach for the Production of Glucose and High-Purity Xylooligosaccharides from Edible Biomass Byproducts
}

\author{
Soo-Kyeong Jang ${ }^{1}$, Chan-Duck Jung ${ }^{2}{ }^{-0}$, Ju-Hyun $\mathrm{Yu}^{2}$ and Hoyong Kim ${ }^{2, *} \mathbb{1}$ \\ 1 Department of Wood Science, Faculty of Forestry, The University of British Columbia, 2424 Main Mall, \\ Vancouver, BC V6T 1Z4, Canada; sookyeong.jang@ubc.ca \\ 2 Center for Bio-Based Chemistry, Korea Research Institute of Chemical Technology, Ulsan 44429, Korea; \\ cksejrl@krict.re.kr (C.-D.J.); jhyu@krict.re.kr (J.-H.Y.) \\ * Correspondence: hykim03@krict.re.kr; Tel.: +82-52-241-6357
}

Received: 26 October 2020; Accepted: 13 November 2020; Published: 16 November 2020

\begin{abstract}
Xylooligosaccharides (XOS) production from sweet sorghum bagasse (SSB) has been barely studied using other edible biomasses. Therefore, we evaluated the XOS content as well as its purity by comparing the content of total sugars from SSB. An environmentally friendly approach involving autohydrolysis was employed, and the reaction temperature and time had variations in order to search for the conditions that would yield high-purity XOS. After autohydrolysis, the remaining solid residues, the glucan-rich fraction, were used as substrates to be enzymatically hydrolyzed for glucose conversion. The highest $\mathrm{XOS}$ was observed for total sugars $(68.7 \%)$ at $190^{\circ} \mathrm{C}$ for $5 \mathrm{~min}$ among the autohydrolysis conditions. However, we also suggested two alternative conditions, $180^{\circ} \mathrm{C}$ for $20 \mathrm{~min}$ and $190^{\circ} \mathrm{C}$ for $15 \mathrm{~min}$, because the former condition might have the XOS at a low degree of polymerization with a high XOS ratio $(67.6 \%)$, while the latter condition presented a high glucose to total sugar ratio $(91.4 \%)$ with a moderate level XOS ratio $(64.4 \%)$. Although it was challenging to conclude on the autohydrolysis conditions required to obtain the best result of XOS content and purity and glucose yield, this study presented approaches that could maximize the desired product from SSB, and additional processes to reduce these differences in conditions may warrant further research.
\end{abstract}

Keywords: xylooligosaccharides; autohydrolysis; enzymatic hydrolysis; sweet sorghum bagasse

\section{Introduction}

Due to an emerging interest in a healthy lifestyle, probiotics have attracted attention [1]. Probiotics have several beneficial effects on the human body, especially as it reduces the risk of colon-related diseases and dysfunctions [2]. Prebiotics have also attracted great interest because they facilitate the growth of probiotics and inhibit the growth of pathogenic microorganisms in the human intestine [3].

Xylooligosaccharides (XOS) are one of the fascinating products of biomass that have unique properties as prebiotics [4]. XOS do not only reduce the risk of colon cancer, but also improve beneficial biological activities, including reducing dental caries, boosting the immune system, and restraining the growth of pathogens [5]. Food and food additives have been recognized as conventional methods for XOS ingestion, but the application area of XOS is expanding the pharmaceutical, chemical, and nutraceutical industries [6]. The global market size of XOS is expected to grow by $4.1 \%$ annually and reach 135.7 million dollars by 2026 [7].

XOS is typically defined as two to ten xylose combined by $\beta-1,4$ linkages with arabinose, acetyl groups, and uronic acid substitution [8]. Chemical (acid pretreatment and autohydrolysis) and 
biological (enzymatic hydrolysis by xylanase) approaches have been developed for hydrolyzing and extracting the xylan chain in a biomass [9]. Concentrated acid pretreatment using inorganic acids has been reported to result in fast isolation of the xylan fraction, but this method is not environmentally friendly and corrodes the equipment [10]. Meanwhile, the biological method can control the generation of byproducts, as shown in the results of acid pretreatment, but it has drawbacks such as long reaction time, relatively low XOS yield, and high cost of xylanase [11,12]. Autohydrolysis is considered an eco-friendly pretreatment method because it does not use any chemicals for the reaction [13]. When a biomass is heated in water, the uronic and acetyl groups from the hemicellulose fraction can be released in the form of an acid followed by acid-hydrolysis of the carbohydrate [14]. This acidic circumstance of autohydrolysis from the side groups of hemicellulose does not lead to an extremely low $\mathrm{pH}$ condition compared to the mineral acids of typical acid pretreatments [15]. Thus, autohydrolysis can be a less corrosive and low-cost approach for XOS production than other chemical methods [13].

Several types of xylan-rich biomasses are used for producing XOS, such as corn stover, wheat straw, sugarcane straw, and sugarcane bagasse [16-19]. However, the straws from agricultural residues usually contain a high amount of minerals, including amorphous silica, which can cause chemical reactions to occur in an undesired manner [20]. The production of numerous XOS has been focused on the utilization of sugarcane bagasse, while interest for sweet sorghum is still lower than that of other biomasses [21]. Sweet sorghum can be cultivated in most regions of the world, from temperate to tropical [22]. It typically grows over $3 \mathrm{~m}$ tall, ensuring a high energy density per cultivating area up to 20.2 tons per ha [23]. Additionally, sweet sorghum bagasse (SSB) contains an abundant amount of xylan, which is an advantage for XOS production [24].

The physiological activities of XOS have been considered to be strongly related to the linkage-type, substituted side groups, and the degree of polymerization (DP) [25]. Regarding the DP, XOS has a low DP from xylobiose $(\mathrm{DP}=2)$ to xylotetraose $(\mathrm{DP}=4)$, and performs better as a prebiotic than XOS with a high DP $[26,27]$. On the other hand, xylose and furfural, which are dehydrated products from xylose, can be excessively produced when high temperature or/and low $\mathrm{pH}$ conditions are induced to focus on the cleavage of the xylan structure [28]. Therefore, suitable autohydrolysis conditions for improving the XOS yield and purity should be investigated. In addition, when the high-valued XOS containing a dominant amount of DP 2-4 XOS produced with additional xylanase treatment as a follow-up step, the optimum conditions can reduce the purification and production costs. In this study, $\mathrm{SSB}$, a promising biomass, was subjected to the autohydrolysis process to produce XOS. The conditions were evaluated for a high ratio of XOS to total sugars. After autohydrolysis, the remaining solid residues, cellulose-rich fraction, were used for enzymatic hydrolysis to produce a glucose solution.

\section{Materials and Methods}

\subsection{Feedstock}

Sweet sorghum (Sorghum bicolor (L.)) bagasse was generously supplied by Good Farmer Co., Ltd., Yecheon-gun, Gyeongsangbuk-do, Korea. The feedstock was oven dried and milled to $<0.5 \mathrm{~mm}$ using a knife mill. The chemical composition of sweet sorghum is shown in Table 1.

Table 1. Chemical composition of sweet sorghum (g/100 g oven dry weight).

\begin{tabular}{lc}
\hline \multicolumn{1}{c}{ Composition $^{\mathbf{1}}$} & Sweet Sorghum Bagasse (SSB) \\
\hline Extractives & $9.3 \pm 0.4$ \\
\hline Carbohydrate & 67.3 \\
Glucan & $37.6 \pm 0.4$ \\
XGM $^{2}$ & $21.2 \pm 0.5$ \\
Arabinan & $2.3 \pm 0.0$ \\
Acetate & $6.1 \pm 0.0$ \\
\hline
\end{tabular}


Table 1. Cont.

\begin{tabular}{|c|c|}
\hline Composition $^{1}$ & Sweet Sorghum Bagasse (SSB) \\
\hline Lignin & 17.2 \\
\hline Acid-insoluble & $15.1 \pm 0.1$ \\
\hline Acid-soluble & $2.1 \pm 0.1$ \\
\hline Ash & $1.1 \pm 0.0$ \\
\hline Crude protein & $6.5 \pm 0.0$ \\
\hline Total & 101.3 \\
\hline
\end{tabular}

\subsection{Autohydrolysis}

Autohydrolysis was conducted to identify a good point to maximize the XOS amount in the liquid hydrolysate. It was carried out using a bomb-type mini-reactor $(30 \mathrm{~mm} \mathrm{ID} \times 140 \mathrm{~mm} \mathrm{~L}$, wall thickness $5 \mathrm{~mm}$, total volume $100 \mathrm{~mL}$, KRICT, Daejeon, Korea), equipped with a K-type thermocouple for monitoring the actual reaction temperature. The reaction temperature was set as a variable from 160 to $200{ }^{\circ} \mathrm{C}$ at $10^{\circ} \mathrm{C}$ intervals. One gram of the oven-dried weight of sweet sorghum bagasse was placed in a custom-made reactor with $20 \mathrm{~mL}$ of water. When the reactor reached the designated reaction temperature in an oil bath, it was held for $20 \mathrm{~min}$ (reaction time). The reaction time was also changed for 180 and $190{ }^{\circ} \mathrm{C}$ conditions from 5 to $20 \mathrm{~min}$ with $5 \mathrm{~min}$ intervals. After autohydrolysis, slurries were recovered from the reactor into a $50 \mathrm{~mL}$ conical tube using an additional $20 \mathrm{~mL}$ of water and separated into a solid residue and liquid hydrolysate by centrifugation.

\subsection{Enzymatic Hydrolysis}

Enzymatic hydrolysis was performed using the solid residue from autohydrolysis. The solid residue obtained from each autohydrolysis condition was directly used as a substrate for the commercial cellulase complex Cellic CTec3 (Novozyme Korea, Seoul, Korea). The dosage of the cellulase complex was $10 \mathrm{FPU} / \mathrm{g}$ glucan in the substrate. The citrate buffer solution was adjusted to $\mathrm{pH} 5.5$, and the mixture was incubated in a shaker at $50{ }^{\circ} \mathrm{C}$ for $72 \mathrm{~h}$ at $150 \mathrm{rpm}$.

The glucose to total sugar ratio was calculated as follow:

$$
\text { Glucose to total sugar ratio }(\%)=\frac{\text { Glucose in the solution after enzymatic hydrolysis }(g)}{\text { Total sugars in the solution after enzymatic hydrolysis }(g)} \times 100
$$

\subsection{Determination of the Chemical Composition}

The chemical composition of the liquid hydrolysate, enzymatic hydrolysis solution, and the raw material (SSB) were determined using the Laboratory Analytical Procedure of NREL $[29,30]$. Furthermore, additional acid hydrolysis using $4 \%$ sulfuric acid solution was conducted to convert all kinds of carbohydrates in the liquid hydrolysate to monomeric sugars. The amount of monomeric sugars was quantified by high-performance liquid chromatography (HPLC) (Agilent 1200 Infinity, Agilent Technologies Korea Inc., Seoul, Korea). HPLC was equipped with an HPX-87H $(300 \times 7.8 \mathrm{~mm})$ column (Bio-Rad, Hercules, CA, USA) and a refractive index detector (RID-6A, Bio-Rad, Hercules, CA, USA). Twenty microliters of sample was injected for the HPLC analysis, and the oven temperature was set at $50{ }^{\circ} \mathrm{C}$. The mobile phase was $5 \mathrm{mM}$ sulfuric acid solution and eluted at a $0.6 \mathrm{~mL} / \mathrm{min}$ flow rate. For quantification, the calibration curves were made using standard materials (glucose, xylose, and arabinose), which were purchased from Sigma-Aldrich Korea Co. (Yongin, Korea). The nitrogen content of SSB was determined with an elemental analyzer (Flash EA 2000, Thermo Electron Corporation, Waltham, MA, USA), and crude protein content was calculated using nitrogen content and conversion factor (6.25) [31]. 
The XOS to total sugar ratio was calculated by following formula:

$$
\text { XOS to total sugar ratio }(\%)=\frac{X O S \text { in the liquid hydrolysate after autohydrolysis }(\mathrm{g})}{\text { Total sugars in the liquid hydrolysate after autohydrolysis }(\mathrm{g})} \times 100
$$

\section{Results}

\subsection{Xylooligosaccharides Production Depending on the Changes of the Reaction Temperature}

Hemicellulose fractions in SSB were released into the liquid hydrolysate in the form of both monomeric and oligomeric sugars after autohydrolysis (Table 2). Hemicellulosic sugars could not be fully hydrolyzed due to the severity of autohydrolysis, and a large amount of oligomeric sugars might be dissolved in the liquid hydrolysate together with monomeric sugars.

Table 2. Chemical composition of the liquid hydrolysate by reaction temperature variables.

\begin{tabular}{|c|c|c|c|c|c|c|c|}
\hline \multicolumn{2}{|l|}{ Conditions } & \multicolumn{3}{|c|}{ Sugars } & \multirow{2}{*}{$\begin{array}{c}\text { Acetic } \\
\text { Acid }\end{array}$} & \multicolumn{2}{|c|}{ Degradation Product } \\
\hline Reaction Temperature $\left({ }^{\circ} \mathrm{C}\right)$ & $\mathrm{pH}$ & Glucose & $\mathrm{XGM}^{1}$ & Arabinose & & HMF $^{2}$ & Furfural \\
\hline 160 & 4.1 & $3.2 \pm 0.1$ & $5.9 \pm 0.9$ & $2.0 \pm 0.1$ & $0.2 \pm 0.0$ & $\mathrm{ND}^{3}$ & ND \\
\hline 170 & 3.8 & $3.7 \pm 0.1$ & $12.2 \pm 0.9$ & $2.2 \pm 0.1$ & $0.4 \pm 0.0$ & ND & ND \\
\hline 180 & 3.7 & $3.9 \pm 0.1$ & $16.9 \pm 0.1$ & $2.1 \pm 0.1$ & $0.8 \pm 0.1$ & ND & $0.2 \pm 0.0$ \\
\hline 190 & 3.5 & $3.9 \pm 0.0$ & $17.9 \pm 0.0$ & $1.6 \pm 0.1$ & $1.5 \pm 0.0$ & ND & $0.8 \pm 0.0$ \\
\hline 200 & 3.3 & $3.8 \pm 0.1$ & $13.9 \pm 0.9$ & $1.0 \pm 0.1$ & $2.4 \pm 0.2$ & $0.2 \pm 0.0$ & $2.3 \pm 0.3$ \\
\hline
\end{tabular}

The release trends of the three kinds of sugars were different depending on the changes in the reaction temperature. The XGM content in the liquid hydrolysate increased by increasing the reaction temperature to $18.4 \%$ based on the initial biomass, while the XGM content sharply decreased at temperatures above $200{ }^{\circ} \mathrm{C}$. Based on the initial arabinan content as monomers, $84.6 \%$ of the arabinose could be released at $170{ }^{\circ} \mathrm{C}$. The hemicellulosic sugars have good solubility in water after autohydrolysis, but the maximum release point was slightly different between XGM and arabinose. The glucose content showed a constant value of approximately $4 \%$ in the liquid hydrolysate. Compared to the initial glucan content in SSB, a small portion of glucose was released from SSB regardless of the reaction temperature changes. Thus, the autohydrolysis could selectively extract XGM in SSB, and the liquid hydrolysate generally had a large amount of XGM and a small amount of glucose and arabinose.

As the reaction temperature increased, the content of monomeric XGM dramatically increased due to the excess hydrolysis of hemicellulose (Figure 1). Meanwhile, XOS content was maximized at $180^{\circ} \mathrm{C}(15.5 \%)$. Similar to the XOS content, the highest XOS to total sugar ratio was achieved at the same reaction temperature $\left(180^{\circ} \mathrm{C}\right)$. Therefore, an appropriate reaction temperature for improving the XOS ratio in the liquid hydrolysate could be found for SSB. 


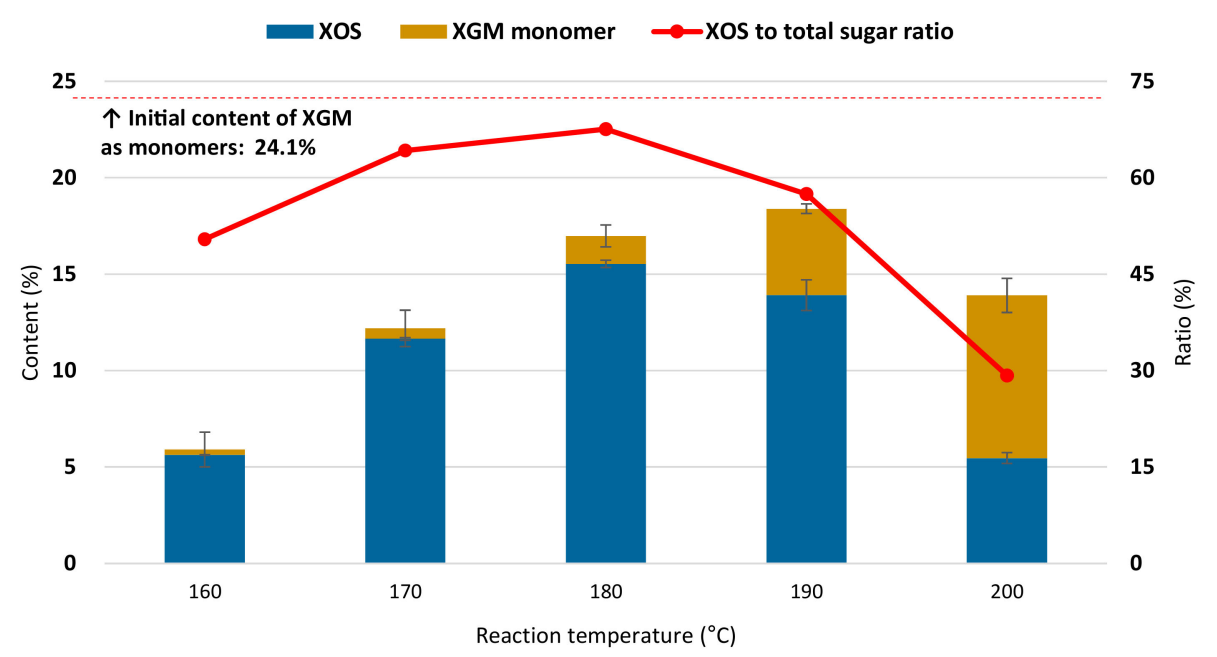

Figure 1. XGM content and XOS to total sugar ratio with the reaction temperature change.

\subsection{Xylooligosaccharides Production Depending on the Changes of the Reaction Time}

The autohydrolysis conditions for XOS production were investigated by changing the reaction time because it has been considered as one of the critical hydrothermal treatment parameters for the control of XOS DP. The reaction time was specified in 5-min intervals within 20 min to confirm the result in a shorter reaction time than that of the previous sections. The reaction temperature was set at 180 and $190^{\circ} \mathrm{C}$, which has a good performance for the high XOS ratio in the liquid hydrolysates.

The XGM content in the liquid hydrolysate was changed by an increase in the reaction time (Table 3). Both reaction temperature conditions presented an increasing trend of XGM content with longer reaction times, except for $20 \mathrm{~min}$ at $190^{\circ} \mathrm{C}$. The maximum XGM content was obtained at $180^{\circ} \mathrm{C}$ for $20 \mathrm{~min}(16.9 \%)$ and $190^{\circ} \mathrm{C}$ for $15 \mathrm{~min}(18.3 \%)$, respectively.

Table 3. Monomeric sugar composition of the liquid hydrolysate by reaction temperature and time variables.

\begin{tabular}{|c|c|c|c|c|c|c|c|}
\hline \multicolumn{2}{|c|}{ Conditions } & \multicolumn{3}{|c|}{ Sugars } & \multirow{2}{*}{$\begin{array}{l}\text { Acetic } \\
\text { Acid }\end{array}$} & \multicolumn{2}{|c|}{ Degradation Product } \\
\hline $\begin{array}{c}\text { Reaction } \\
\text { Temperature }\left({ }^{\circ} \mathrm{C}\right)\end{array}$ & $\begin{array}{l}\text { Reaction } \\
\text { Time (min) }\end{array}$ & Glucose & $\mathrm{XGM}^{1}$ & Arabinose & & HMF $^{2}$ & Furfural \\
\hline \multirow{4}{*}{180} & 5 & $3.5 \pm 0.2$ & $11.3 \pm 1.3$ & $1.5 \pm 1.1$ & $0.4 \pm 0.0$ & $\mathrm{ND}^{3}$ & $0.1 \pm 0.0$ \\
\hline & 10 & $3.8 \pm 0.1$ & $13.6 \pm 0.8$ & $2.1 \pm 0.1$ & $0.6 \pm 0.2$ & ND & $0.1 \pm 0.0$ \\
\hline & 15 & $3.9 \pm 0.0$ & $15.5 \pm 0.9$ & $2.1 \pm 0.0$ & $0.6 \pm 0.1$ & ND & $0.1 \pm 0.0$ \\
\hline & 20 & $3.9 \pm 0.1$ & $16.9 \pm 0.1$ & $2.1 \pm 0.1$ & $0.8 \pm 0.1$ & ND & $0.2 \pm 0.0$ \\
\hline \multirow{4}{*}{190} & 5 & $3.8 \pm 0.0$ & $15.6 \pm 1.2$ & $2.0 \pm 0.0$ & $0.7 \pm 0.2$ & ND & $0.1 \pm 0.1$ \\
\hline & 10 & $3.8 \pm 0.2$ & $16.9 \pm 0.7$ & $1.9 \pm 0.1$ & $0.9 \pm 0.1$ & ND & $0.3 \pm 0.1$ \\
\hline & 15 & $3.9 \pm 0.0$ & $18.3 \pm 0.2$ & $1.8 \pm 0.1$ & $1.2 \pm 0.2$ & ND & $0.5 \pm 0.1$ \\
\hline & 20 & $3.9 \pm 0.0$ & $17.9 \pm 0.0$ & $1.6 \pm 0.0$ & $1.5 \pm 0.0$ & ND & $0.8 \pm 0.0$ \\
\hline
\end{tabular}

${ }^{1}$ Sum of xylose, galactose, and mannose; ${ }^{2}$ Hydroxymethylfurfural; ${ }^{3}$ Not detected.

Although a good maximum XGM content was obtained at $190^{\circ} \mathrm{C}$ than at $180^{\circ} \mathrm{C}$, the results of the XOS to total sugar ratio are quite different between the two conditions (Figure 2). In the cases of $180^{\circ} \mathrm{C}$, the XOS to total sugar ratio was constant even though the reaction time was changed (Figure 2a). Meanwhile, the ratio showed a sharp decrease as the reaction time was extended to $20 \mathrm{~min}$ at $190{ }^{\circ} \mathrm{C}$ (Figure $2 \mathrm{~b}$ ). Although $180^{\circ} \mathrm{C}$ for 20 min showed the highest XOS content $(15.4 \%)$, this condition could not guarantee the highest level of XOS to total sugar ratio $(67.7 \%)$. Therefore, $190{ }^{\circ} \mathrm{C}$ for $5 \mathrm{~min}$ might 
be considered as the best point for XOS production from SSB due to the high content of XOS (14.7\%) and high purity (XOS to total sugar ratio: 68.7\%) than other autohydrolysis conditions.

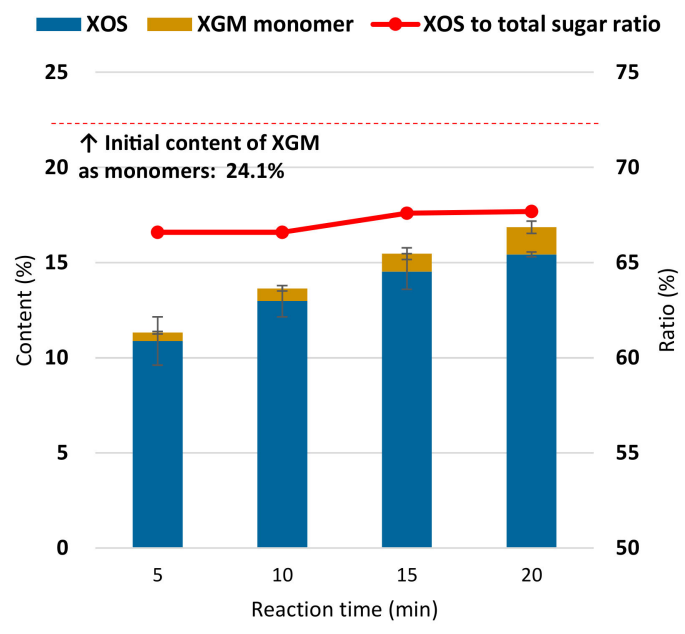

(a)

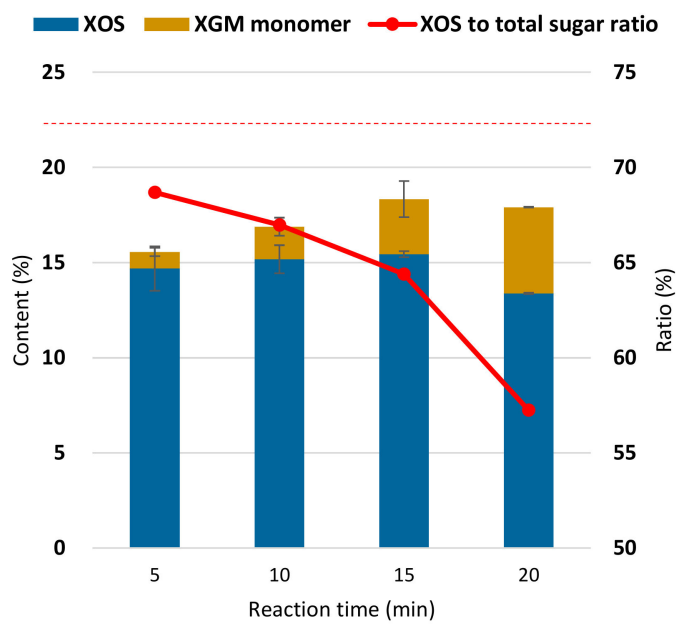

(b)

Figure 2. XGM content and XOS to total sugar ratio with reaction time change: (a) $180{ }^{\circ} \mathrm{C}$; (b) $190{ }^{\circ} \mathrm{C}$.

\subsection{Glucose Conversion Depending on the Reaction Temparature Changes}

The cellulose fraction in the solid residues after autohydrolysis was hydrolyzed to glucose by an enzyme cocktail (Figure 3). According to the sugar composition in the liquid hydrolysate, a small amount of glucose was released regardless of the changes in the reaction temperature (Table 1). However, the glucose yield after enzymatic hydrolysis showed an increasing trend with increasing reaction temperature. The glucose to total sugar ratio presented a similar trend with the glucose yield corresponding to the reaction temperature increase. Thus, the maximum glucose yield (36.6\%) and glucose to total sugar ratio $(94.2 \%)$ were obtained at $200{ }^{\circ} \mathrm{C}$.

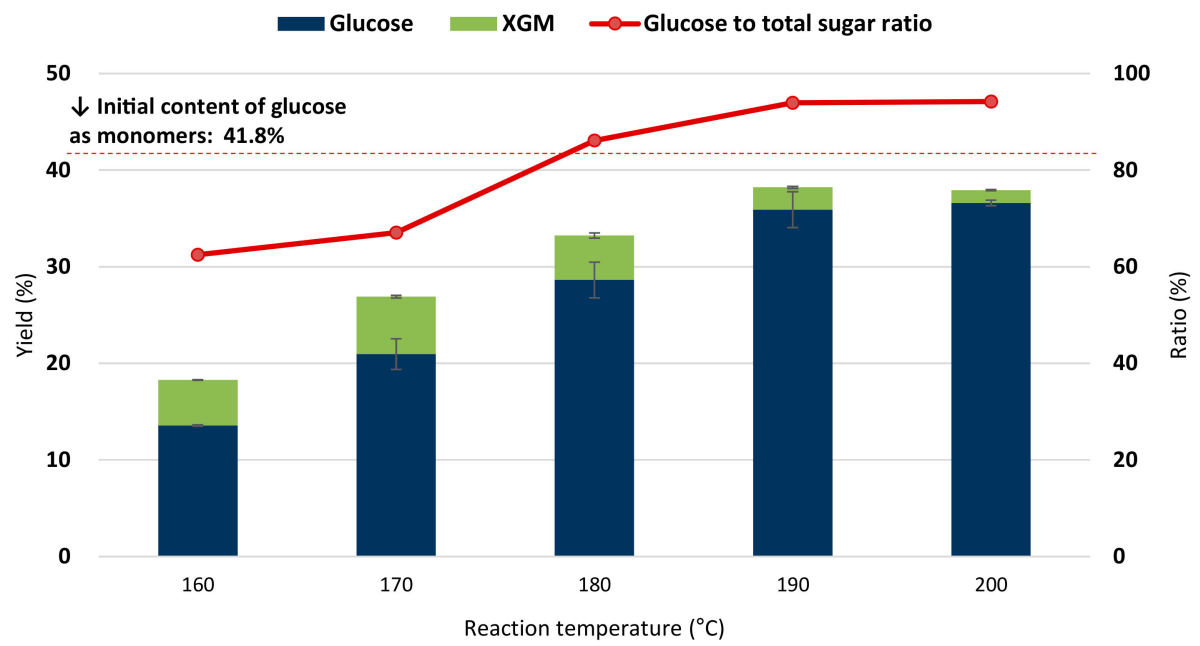

Figure 3. Glucose yield and glucose to total sugar ratio after enzymatic hydrolysis.

\subsection{Glucose Conversion Depending on the Changes of the Reaction Time}

The glucose yield was improved by extending the reaction time under both reaction temperature conditions (Figure 4). In addition, the glucose to total sugar ratio was maximized at $20 \mathrm{~min}$, but the results were slightly different between the $180^{\circ} \mathrm{C}(86.2 \%)$ and $190^{\circ} \mathrm{C}(93.9 \%)$ conditions. However, 
it was revealed that a condition with a high glucose to total sugar ratio does not ensure a high XOS to total sugar ratio by comparing the results of the previous section.

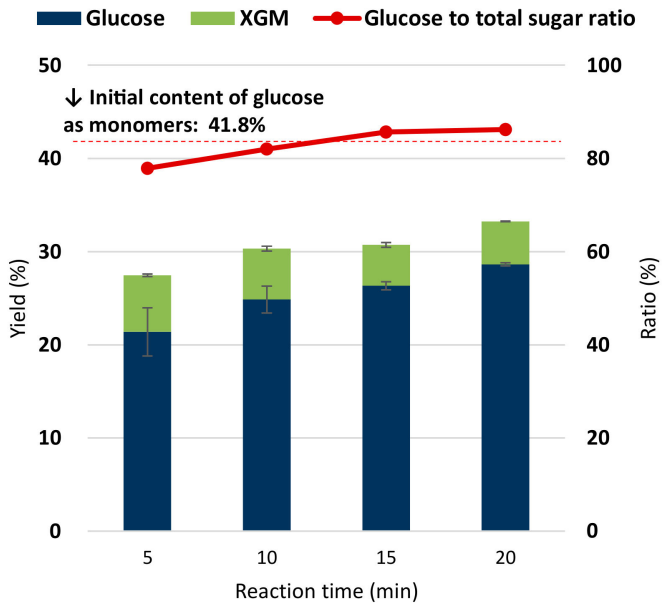

(a)

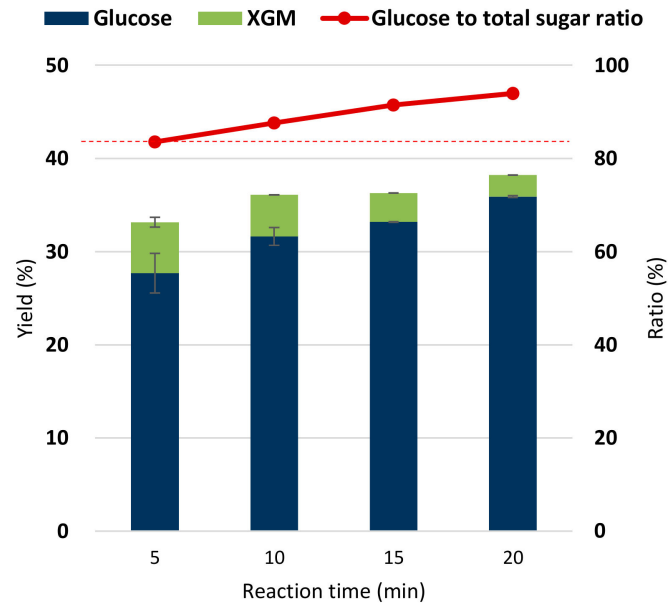

(b)

Figure 4. Glucose content and conversion ratio after enzymatic hydrolysis: (a) $180{ }^{\circ} \mathrm{C}$; (b) $190{ }^{\circ} \mathrm{C}$.

This trade-off relationship between XOS and glucose is obvious in the mass balance profile of this study (Figure 5). This figure suggests three autohydrolysis conditions: the first and second conditions represent the highest XOS to total sugar ratio at 180 and $190{ }^{\circ} \mathrm{C}$, respectively. At $190{ }^{\circ} \mathrm{C}$ for $5 \mathrm{~min}$, the XOS to total sugar ratio was higher $(68.7 \%)$ than that at $180^{\circ} \mathrm{C}$ for $20 \mathrm{~min}(67.6 \%)$. Meanwhile, the $180^{\circ} \mathrm{C}$ condition has a superb result for the glucose to total sugars ratio $(86.2 \%)$ than the $180^{\circ} \mathrm{C}$ result (83.5\%). Meanwhile, the $190^{\circ} \mathrm{C}$ for $15 \mathrm{~min}$ condition presented a higher number of glucose to total sugar ratios $(91.4 \%)$ compared to the two previous conditions, even though this condition had a moderate level of XOS to total sugar ratio $(64.4 \%)$. Therefore, the autohydrolysis condition should be properly considered for optimizing the production of major products from SSB.

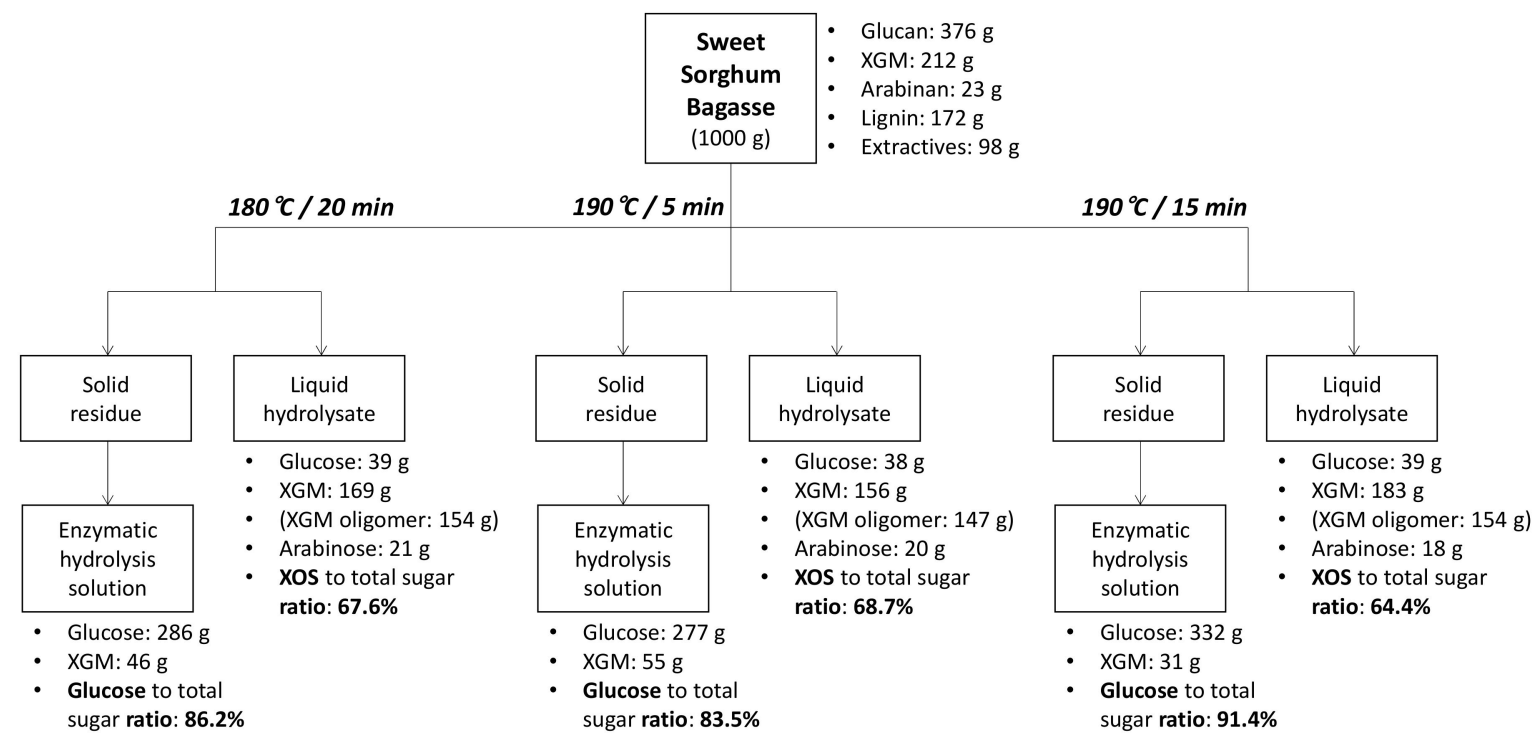

Figure 5. Mass balance of the XOS and glucose production from sweet sorghum bagasse.

\section{Discussion}

Numerous studies have attempted to improve the release performance of XOS from biomasses that directly connected the productivity of XOS [16-19]. However, control of impurities in the liquid 
fraction after treatment is considered a major factor affecting the market price of XOS as well as its yield $[2,32]$. Due to the fact that the purification process of XOS is costly, it can dramatically increase if a high amount of impurities are simultaneously mixed with XOS [28]. Another reason for the importance of controlling the impurities is related to the XOS activity [26]. In other words, the concept of impurity can be expanded to monomeric sugars, such as xylose [33]. XOS has several beneficial activities for the human body as a prebiotic, while xylose does not have any function like XOS [34]. Thus, preventing the excess generation of xylose is an essential factor for increasing the productivity of XOS.

The chemical composition of SSB showed good potential for XOS production (Table 1). It had a high amount of xylan, and a low amount of ash and other hemicellulosic sugars. In particular, a very tiny amount of galactan and mannan in SSB has been reported in previous studies $[35,36]$. Therefore, the XGM monomer in the liquid hydrolysate can be considered as xylose alone, and the XGM oligomer implied XOS in this study.

The acid-hydrolysis pathway of xylan is shown by the variation of the XGM content with an increase in the reaction temperature (Table 2). The xylan seemed to be fully degraded and dissolved in liquid hydrolysate at $190^{\circ} \mathrm{C}$. Then, the XGM content sharply dropped at $200{ }^{\circ} \mathrm{C}$ because it converted to $\mathrm{HMF}$ and furfural, which are degradation products. The $\mathrm{pH}$ level gradually decreased by providing more heat energy due to the cleavage of the acetyl group from the hemicellulose chain, which resulted in more acidic circumstances at higher reaction temperature conditions [37]. This means that xylan degradation might be accelerated by positive feedback from heat energy and acids during autohydrolysis. This phenomenon was revealed by the variation in the XGM monomer content, which increased more in the higher reaction temperature conditions (Figure 1). Thus, autohydrolysis proved that the xylan structure in SSB can be sufficiently decomposed without the addition of chemical catalysts.

As mentioned above, the quality of XOS might be controlled by reducing the impurities, including the monomeric sugars. In this term, the ratio between the XOS and the sum of glucose, arabinose, and XGM monomer in the liquid hydrolysate was calculated to evaluate the quality of XOS, and it was named XOS to total sugar ratio in this study. In other words, the XOS to total sugar ratio implies the proportion of XOS compared to the total sugars in the liquid hydrolysate. When the autohydrolysis conditions had a designated reaction time $(20 \mathrm{~min})$, the $170^{\circ} \mathrm{C}$ condition showed a better XOS to total sugar ratio $(64.2 \%)$ than that at $190{ }^{\circ} \mathrm{C}(57.5 \%)$ (Figure 1$)$. The liquid hydrolysate at $170{ }^{\circ} \mathrm{C}$ might have fewer impurities than that at $190{ }^{\circ} \mathrm{C}$, but the quantity of XOS and monomers at $190{ }^{\circ} \mathrm{C}(13.9 \%$ and $4.5 \%)$ was higher than that at $170{ }^{\circ} \mathrm{C}(11.6 \%$ and $0.5 \%)$. Considering the acid-hydrolysis pathway of xylan during autohydrolysis, the high amount of XGM monomer implies that the liquid hydrolysate at $190^{\circ} \mathrm{C}$ could have a higher amount of low DP of XOS than that at $170^{\circ} \mathrm{C}$ [38]. According to previous research, the low DP of XOS presented performed better as a prebiotic than high DP (above 4) of XOS [39].

$180^{\circ} \mathrm{C}$, which had the highest XOS to total sugar ratio, and $190^{\circ} \mathrm{C}$ conditions were selected for evaluating XOS production from SSB with several variations of the reaction time (Figure 3). The highest XOS content $(15.4 \%)$ in this study was obtained at $180^{\circ} \mathrm{C}$ for $20 \mathrm{~min}$ and $190{ }^{\circ} \mathrm{C}$ for $15 \mathrm{~min}$. This XOS content can be converted to conversion ratio based on the initial amount of xylan in SSB $(64.1 \%)$, which may be considered as a noteworthy value compared with the results of previous autohydrolysis studies: $60.9 \%$ from miscanthus [32], 61\% from the brewery's spent grain [40], 51.7\% from rice husks, and $51.8 \%$ from corn cob [41].

Glucan was presented as a major carbohydrate in SSB, even though it contained twice as much as the XGM in this study. Glucose has been recognized as a platform chemical from biomass and can be easily produced by enzymatic hydrolysis if the cell wall structure is appropriately degraded by the pretreatment [42]. The glucose to total sugar ratio, which was calculated in the same manner as the case of XOS, gradually increased with an increase in the reaction temperature and time (Figures 2 and 4). Meanwhile, less than $4 \%$ of glucose was released into the liquid hydrolysate even at the highest reaction temperature (Tables 2 and 3). This means that the amount of remaining glucan had not changed much by changing the autohydrolysis conditions, but the cell wall structure might be 
degraded toward a suitable form for cellulase activity at high reaction temperatures and long reaction times. The highest glucose to total sugar ratio (94.2\%) was observed at $200{ }^{\circ} \mathrm{C}$ for $20 \mathrm{~min}$, and an indication of glucan degradation could not be found under the autohydrolysis conditions in this study.

The ideal autohydrolysis condition for XOS production could be suggested by the variations in reaction temperature and time (Figure 5). A XOS to total sugar ratio of $68.7 \%$ was obtained at $190{ }^{\circ} \mathrm{C}$ for $5 \mathrm{~min}$, and a short reaction time can be an advantage for large-scale plants [43]. However, the result of this condition is concerned that the XOS might consist of a significant amount of high DP of XOS. According to this assumption, the liquid hydrolysate under this condition may require further processing to reduce the DP by xylanase. Additionally, this condition showed a relatively low glucose to total sugar ratio $(83.5 \%)$, another main product of autohydrolysis, than other conditions. In this term, $180^{\circ} \mathrm{C}$ for $20 \mathrm{~min}$ can be an alternative to $190^{\circ} \mathrm{C}$ for $5 \mathrm{~min}$ because the XOS to total sugar ratio in this condition $(67.6 \%)$ is slightly lower than that at $190^{\circ} \mathrm{C}$ for $5 \mathrm{~min}$. Meanwhile, the higher XGM monomer content $(1.4 \%)$ in this condition means that the average DP might be lower than that $190{ }^{\circ} \mathrm{C}$ for $5 \mathrm{~min}$. If xylanase treatment followed by autohydrolysis induces the formation of XOS with a narrow DP from 2 to 4 , the XOS DP variation in the liquid hydrolysate should be considered as an important factor in determining the amount of xylanase consumed. In this regard, $180^{\circ} \mathrm{C}$ for 20 min might be more favorable for producing high-value XOS than at $190{ }^{\circ} \mathrm{C}$ for $5 \mathrm{~min}$. On the other hand, $190{ }^{\circ} \mathrm{C}$ for $15 \mathrm{~min}$ can be chosen to obtain a high purity of glucose, $91.4 \%$ of glucose to total sugar ratio, even though this condition showed a moderate level of XOS to total sugar ratio $(64.4 \%)$. This trade-off relationship between XOS and glucose might be controlled by inducing an additional process between the autohydrolysis and enzymatic hydrolysis steps. For instance, mechanical refining can be employed for solid residues, and it improves glucose conversion by collapsing the cell wall structure, even though the solid residue is produced under low reaction temperature conditions [44].

\section{Conclusions}

The xylan-rich edible biomass, SSB, was utilized for XOS and glucose production using the autohydrolysis process. The purity of XOS was improved by controlling the autohydrolysis conditions, and XOS to total sugar ratio was maximized by up to $68.7 \%$, which is expected to reduce production costs for the purification process. However, both XOS purity and content should be considered to determine the optimum conditions for XOS production. On the other hand, the remaining solid residue after autohydrolysis was successfully converted to glucose by enzymatic hydrolysis, and the highest glucose to total sugar ratio was $94.2 \%$. Although there was a discrepancy between the ideal conditions for XOS and glucose production, the results of this study can be useful in selecting the suitable autohydrolysis condition for improving the production of the desired material from SSB.

Author Contributions: Conceptualization, H.K.; methodology, C.-D.J. and H.K.; validation, H.K.; formal analysis, C.-D.J.; investigation, C.-D.J. and H.K.; resources J.-H.Y. and H.K.; data curation, S.-K.J. and H.K.; writing-original draft preparation, S.-K.J.; writing-review and editing, S.-K.J. and H.K.; visualization, S.-K.J.; supervision, H.K.; project administration, H.K.; funding acquisition, H.K. All authors have read and agreed to the published version of the manuscript.

Funding: This work was supported by the Korea Research Institute of Chemical Technology (KRICT, Korea) project (SS2042-10) and R\&D Program (20008416) of the Ministry of Trade, Industry \& Energy (MOTIE/KEIT, Korea).

Conflicts of Interest: The authors declare no conflict of interest.

\section{References}

1. Amorim, C.; Silvério, S.C.; Prather, K.L.; Rodrigues, L.R. From lignocellulosic residues to market: Production and commercial potential of xylooligosaccharides. Biotechnol. Adv. 2019, 37, 107397. [CrossRef] [PubMed]

2. Aachary, A.A.; Prapulla, S.G. Xylooligosaccharides (XOS) as an emerging prebiotic: Microbial synthesis, utilization, structural characterization, bioactive properties, and applications. Compr. Rev. Food Sci. Food Saf. 2011, 10, 2-16. [CrossRef] 
3. Bhatia, R.; Winters, A.; Bryant, D.N.; Bosch, M.; Clifton-Brown, J.; Leak, D.; Gallagher, J. Pilot-scale production of xylo-oligosaccharides and fermentable sugars from Miscanthus using steam explosion pretreatment. Bioresour. Technol. 2020, 296, 122285. [CrossRef] [PubMed]

4. Swennen, K.; Courtin, C.M.; Delcour, J.A. Non-digestible oligosaccharides with prebiotic properties. Crit. Rev. Food Sci. Nutr. 2006, 46, 459-471. [CrossRef] [PubMed]

5. Singh, R.; Banerjee, J.; Sasmal, S.; Muir, J.; Arora, A. High xylan recovery using two stage alkali pre-treatment process from high lignin biomass and its valorisation to xylooligosaccharides of low degree of polymerisation. Bioresour. Technol. 2018, 256, 110-117. [CrossRef]

6. Xiao, X.; Bian, J.; Peng, X.-P.; Xu, H.; Xiao, B.; Sun, R.-C. Autohydrolysis of bamboo (Dendrocalamus giganteus Munro) culm for the production of xylo-oligosaccharides. Bioresour. Technol. 2013, 138, 63-70. [CrossRef]

7. Xylooligosaccharides (XOS) Market Size 2020 Analysis by CAGR of 4.1\%, I.S., Business Strategies, Emerging Demands, Growth Rate, Recent Trends, Opportunity, and Forecast to 2026. Available online: https://www.marketwatch.com/press-release/xylooligosaccharides-xos-market-size-2020-analysis-by-cagr -of-41-industry-share-business-strategies-emerging-demands-growth-rate-recent-trends-opportunity-a nd-forecast-to-2026-2020-07-12 (accessed on 20 September 2020).

8. Bian, J.; Peng, F.; Peng, X.-P.; Peng, P.; Xu, F.; Sun, R.-C. Structural features and antioxidant activity of xylooligosaccharides enzymatically produced from sugarcane bagasse. Bioresour. Technol. 2013, 127, 236-241. [CrossRef]

9. Zhang, W.; You, Y.; Lei, F.; Li, P.; Jiang, J. Acetyl-assisted autohydrolysis of sugarcane bagasse for the production of xylo-oligosaccharides without additional chemicals. Bioresour. Technol. 2018, 265, 387-393. [CrossRef]

10. Chen, H.; Liu, J.; Chang, X.; Chen, D.; Xue, Y.; Liu, P.; Lin, H.; Han, S. A review on the pretreatment of lignocellulose for high-value chemicals. Fuel Process. Technol. 2017, 160, 196-206. [CrossRef]

11. Qing, Q.; Li, H.; Kumar, R.; Wyman, C.E. Xylooligosaccharides production, quantification, and characterization in context of lignocellulosic biomass pretreatment. Aqueous Pretreat. Plant Biomass Biol. Chem. Convers. Fuels Chem. 2013, 391-415.

12. Poletto, P.; Pereira, G.N.; Monteiro, C.R.; Pereira, M.A.F.; Bordignon, S.E.; de Oliveira, D. Xylooligosaccharides: Transforming the lignocellulosic biomasses into valuable 5-carbon sugar prebiotics. Process Biochem. 2020, 91, 352-363. [CrossRef]

13. Garrote, G.; Domínguez, H.; Parajó, J.C. Mild autohydrolysis: An environmentally friendly technology for xylooligosaccharide production from wood. J. Chem. Technol. Biotechnol. 1999, 74, 1101-1109. [CrossRef]

14. Lachos-Perez, D.; Martinez-Jimenez, F.; Rezende, C.; Tompsett, G.; Timko, M.; Forster-Carneiro, T. Subcritical water hydrolysis of sugarcane bagasse: An approach on solid residues characterization. J Supercrit. Fluids 2016, 108, 69-78. [CrossRef]

15. Kumar, L.; Tooyserkani, Z.; Sokhansanj, S.; Saddler, J.N. Does densification influence the steam pretreatment and enzymatic hydrolysis of softwoods to sugars? Bioresour. Technol. 2012, 121, 190-198. [CrossRef] [PubMed]

16. Carvalho, A.F.A.; Marcondes, W.F.; de Oliva Neto, P.; Pastore, G.M.; Saddler, J.N.; Arantes, V. The potential of tailoring the conditions of steam explosion to produce xylo-oligosaccharides from sugarcane bagasse. Bioresour. Technol. 2018, 250, 221-229. [CrossRef]

17. Oliveira, F.M.; Pinheiro, I.O.; Souto-Maior, A.M.; Martin, C.; Gonçalves, A.R.; Rocha, G.J. Industrial-scale steam explosion pretreatment of sugarcane straw for enzymatic hydrolysis of cellulose for production of second generation ethanol and value-added products. Bioresour. Technol. 2013, 130, 168-173. [CrossRef]

18. Liu, Z.-H.; Qin, L.; Pang, F.; Jin, M.-J.; Li, B.-Z.; Kang, Y.; Dale, B.E.; Yuan, Y.-J. Effects of biomass particle size on steam explosion pretreatment performance for improving the enzyme digestibility of corn stover. Ind. Crops Prod. 2013, 44, 176-184. [CrossRef]

19. Álvarez, C.; González, A.; Negro, M.J.; Ballesteros, I.; Oliva, J.M.; Sáez, F. Optimized use of hemicellulose within a biorefinery for processing high value-added xylooligosaccharides. Ind. Crops Prod. 2017, 99, 41-48. [CrossRef]

20. Menandro, L.M.S.; Cantarella, H.; Franco, H.C.J.; Kölln, O.T.; Pimenta, M.T.B.; Sanches, G.M.; Rabelo, S.C.; Carvalho, J.L.N. Comprehensive assessment of sugarcane straw: Implications for biomass and bioenergy production. Biofuel Bioprod. Bior. 2017, 11, 488-504. [CrossRef] 
21. Silva, T.A.L.; Zamora, H.D.Z.; Varão, L.H.R.; Prado, N.S.; Baffi, M.A.; Pasquini, D. Effect of steam explosion pretreatment catalysed by organic acid and alkali on chemical and structural properties and enzymatic hydrolysis of sugarcane bagasse. Waste Biomass Valorization 2018, 9, 2191-2201. [CrossRef]

22. Reddy, B.V.; Kumar, A.A.; Ramesh, S. Sweet Sorghum: A Water Saving Bio-Energy Crop; ICRISAT: Patancheru, India, 2007.

23. Erickson, J.E.; Woodard, K.R.; Sollenberger, L.E. Optimizing sweet sorghum production for biofuel in the southeastern USA through nitrogen fertilization and top removal. Bioenergy Res. 2012, 5, 86-94. [CrossRef]

24. Koo, B.; Park, J.; Gonzalez, R.; Jameel, H.; Park, S. Two-stage autohydrolysis and mechanical treatment to maximize sugar recovery from sweet sorghum bagasse. Bioresour. Technol. 2019, 276, 140-145. [CrossRef] [PubMed]

25. Hughes, S.; Shewry, P.; Li, L.; Gibson, G.; Sanz, M.; Rastall, R. In vitro fermentation by human fecal microflora of wheat arabinoxylans. J. Agric. Food. Chem. 2007, 55, 4589-4595. [CrossRef] [PubMed]

26. Ho, A.L.; Kosik, O.; Lovegrove, A.; Charalampopoulos, D.; Rastall, R.A. In vitro fermentability of xylo-oligosaccharide and xylo-polysaccharide fractions with different molecular weights by human faecal bacteria. Carbohydr. Polym. 2018, 179, 50-58. [CrossRef] [PubMed]

27. Ruiz, E.; Gullón, B.; Moura, P.; Carvalheiro, F.; Eibes, G.; Cara, C.; Castro, E. Bifidobacterial growth stimulation by oligosaccharides generated from olive tree pruning biomass. Carbohydr. Polym. 2017, 169, 149-156. [CrossRef]

28. Otieno, D.O.; Ahring, B.K. A thermochemical pretreatment process to produce xylooligosaccharides (XOS), arabinooligosaccharides (AOS) and mannooligosaccharides (MOS) from lignocellulosic biomasses. Bioresour. Technol. 2012, 112, 285-292. [CrossRef]

29. Sluiter, A.; Hames, B.; Ruiz, R.; Scarlata, C.; Sluiter, J.; Templeton, D. Determination of Sugars, Byproducts, and Degradation Products in Liquid Fraction Process Samples. 2006. Available online: https://www.nrel.gov /docs/gen/fy08/42623.pdf (accessed on 27 October 2020).

30. Sluiter, A.; Hames, B.; Ruiz, R.; Scarlata, C.; Sluiter, J.; Templeton, D.; Crocker, D. Determination of structural carbohydrates and lignin in biomass. Lab. Anal. Proced. 2008, 1617,1-16.

31. Salo-väänänen, P.P.; Koivistoinen, P.E. Determination of protein in foods: Comparison of net protein and crude protein $(\mathrm{N} \times 6.25)$ values. Food Chem. 1996, 57, 27-31. [CrossRef]

32. Chen, M.-H.; Bowman, M.J.; Dien, B.S.; Rausch, K.D.; Tumbleson, M.; Singh, V. Autohydrolysis of Miscanthus $\mathrm{x}$ giganteus for the production of xylooligosaccharides (XOS): Kinetics, characterization and recovery. Bioresour. Technol. 2014, 155, 359-365. [CrossRef]

33. Gullón, P.; Moura, P.; Esteves, M.a.P.; Girio, F.M.; Domínguez, H.; Parajó, J.C. Assessment on the fermentability of xylooligosaccharides from rice husks by probiotic bacteria. J. Agric. Food. Chem. 2008, 56, 7482-7487. [CrossRef]

34. Moura, P.; Barata, R.; Carvalheiro, F.; Gírio, F.; Loureiro-Dias, M.C.; Esteves, M.P. In vitro fermentation of xylo-oligosaccharides from corn cobs autohydrolysis by Bifidobacterium and Lactobacillus strains. LWT 2007, 40, 963-972. [CrossRef]

35. Sun, S.; Wen, J.; Sun, S.; Sun, R.-C. Systematic evaluation of the degraded products evolved from the hydrothermal pretreatment of sweet sorghum stems. Biotechnol. Biofuels 2015, 8, 37. [CrossRef] [PubMed]

36. Pham, H.T.T.; Nghiem, N.P.; Kim, T.H. Near theoretical saccharification of sweet sorghum bagasse using simulated green liquor pretreatment and enzymatic hydrolysis. Energy 2018, 157, 894-903. [CrossRef]

37. Wei, H.; Chen, X.; Shekiro, J.; Kuhn, E.; Wang, W.; Ji, Y.; Kozliak, E.; Himmel, M.E.; Tucker, M.P. Kinetic modelling and experimental studies for the effects of Fe2+ ions on xylan hydrolysis with dilute-acid pretreatment and subsequent enzymatic hydrolysis. Catalysts 2018, 8, 39. [CrossRef]

38. Surek, E.; Buyukkileci, A.O. Production of xylooligosaccharides by autohydrolysis of hazelnut (Corylus avellana L.) shell. Carbohydr. Polym. 2017, 174, 565-571. [CrossRef] [PubMed]

39. Childs, C.E.; Röytiö, H.; Alhoniemi, E.; Fekete, A.A.; Forssten, S.D.; Hudjec, N.; Lim, Y.N.; Steger, C.J.; Yaqoob, P.; Tuohy, K.M. Xylo-oligosaccharides alone or in synbiotic combination with Bifidobacterium animalis subsp. lactis induce bifidogenesis and modulate markers of immune function in healthy adults: A double-blind, placebo-controlled, randomised, factorial cross-over study. Br. J. Nutr. 2014, 111, 1945-1956. [CrossRef]

40. Carvalheiro, F.; Esteves, M.; Parajó, J.; Pereira, H.; Grrio, F. Production of oligosaccharides by autohydrolysis of brewery's spent grain. Bioresour. Technol. 2004, 91, 93-100. [CrossRef] 
41. Garrote, G.; Falqué, E.; Domínguez, H.; Parajó, J.C. Autohydrolysis of agricultural residues: Study of reaction byproducts. Bioresour. Technol. 2007, 98, 1951-1957. [CrossRef]

42. Zakaria, M.R.; Hirata, S.; Hassan, M.A. Hydrothermal pretreatment enhanced enzymatic hydrolysis and glucose production from oil palm biomass. Bioresour. Technol. 2015, 176, 142-148. [CrossRef]

43. Jeon, H.; Kang, K.-E.; Jeong, J.-S.; Gong, G.; Choi, J.-W.; Abimanyu, H.; Ahn, B.S.; Suh, D.-J.; Choi, G.-W. Production of anhydrous ethanol using oil palm empty fruit bunch in a pilot plant. Biomass Bioenergy 2014, 67, 99-107. [CrossRef]

44. Park, J.; Jones, B.; Koo, B.; Chen, X.; Tucker, M.; Yu, J.-H.; Pschorn, T.; Venditti, R.; Park, S. Use of mechanical refining to improve the production of low-cost sugars from lignocellulosic biomass. Bioresour. Technol. 2016, 199, 59-67. [CrossRef] [PubMed]

Publisher's Note: MDPI stays neutral with regard to jurisdictional claims in published maps and institutional affiliations.

(C) 2020 by the authors. Licensee MDPI, Basel, Switzerland. This article is an open access article distributed under the terms and conditions of the Creative Commons Attribution (CC BY) license (http://creativecommons.org/licenses/by/4.0/). 